\title{
Table of Equivalents
}

1 hu or shih $=10$ tou $=100$ sheng $=0.565$ United States bushels

$1 p^{\prime} i=4$ chang

1 chang $=7$ feet, 6.94 inches English measure

$1 l i=1864.1+$ English feet

1 catty $($ chin $)=244$ grams

cash $\left(c h^{\prime} i e n\right)=$ copper coins

10,000 copper coins $=1$ catty of actual gold $=244$ grams 